\title{
Microbial Population of Shredded Carrot in Modified Atmosphere Packaging as Related to Irradiation Treatment
}

\author{
ROBERT D. HAGENMAIER and ROBERT A. BAKER
}

\begin{abstract}
Shredded carrots in modified atmosphere packaging were treated with low-dose irradiation of $0.5 \mathrm{kGy}$ in order to determine whether additional reduction of microbial population would be achieved for carrots previously treated with chlorine. Commercially prepared shredded carrots treated with irradiation had a mean microbial population of $1300 \mathrm{CFU} / \mathrm{g}$ at the expiration date (9 days after irradiation) compared with $87,000 \mathrm{CFU} / \mathrm{g}$ for nonirradiated, chlorinated controls. Oxygen content of the headspace gas and ethanol content of the carrots were not significantly affected. Irradiation appears to be a suitable technology for shredded carrots.

Key Words: carrot, irradiation, minimally processed
\end{abstract}

\section{INTRODUCTION}

LIKE OTHER MINIMALLY PROCESSED (FRESH-CUT) VEGETABLES, shredded carrots may have high levels of microorganisms (Brackett, 1994). In commercial shredded carrots, mesophilic counts of about $10^{6}$ to $10^{7}$ have been reported (Nguyen-the and Carlin, 1994, Marchetti et al., 1992, Chervin and Boisseau, 1994). Commercial processes for preparing fresh-cut carrots usually use chlorine in the wash water to control the microbial population. However, chlorine cannot be relied on to eliminate pathogenic microorganisms such as Listeria monocytogenes (Nguyen-the and Carlin, 1994). Irradiation has been shown to be effective in reducing the microbial population of shredded carrots. Doses up to $2 \mathrm{kGy}$ did not lessen the sensory quality of carrots (Chervin and Boisseau, 1994; Scandella and Foures, 1987). However, the maximum dose permitted in the U.S. is $1 \mathrm{kGy}$ (FDA, 1995), which has been inadequate to provide low microbial populations. We were interested in combining chlorination and irradiation as two 'hurdles' for possible reduction of microbial populations (Wiley, 1994).

One hazard associated with reduction of microbial populations is the possibility that pathogenic bacteria may grow to dangerous levels if the shelf life is overly extended. Furthermore, for modified atmosphere packaging (MAP) of fresh produce growth of $C$. botulinum may be enhanced by reduction of competing microorganisms. The Food Code acknowledges that a food with "a high level of competing organisms" does not support growth of C. botulinum when reduced oxygen packaging is used (U.S. Public Health Service and FDA, 1995).

Our objective was to determine what effects irradiation may have, in combination with chlorine and MAP, in the preparation of fresh-cut carrots of low microbial count. Assuming that a general reduction in microbial count results in less risk, irradiated carrots might be of value as food for that segment of the population termed as YOPI: the young, old, pregnant and immunocompromised (Baird-Parker, 1994), some of whom are advised at present to avoid eating salads (Remington and Schimpff, 1981; Bendig and Strangeways, 1989).

The authors are affiliated with the U.S. Citrus \& Subtropical Products Laboratory, USDA, ARS, South Atlantic Area, P.O. Box 1909, Winter Haven, FL 33883-1909.

\section{MATERIALS \& METHODS}

\section{Preparation of carrot samples}

Apache carrots, grown in Zellwood, FL, were used. These were processed in a commercial, state-of-the-art processing fresh-cut facility located in Florida. Carrots were rinsed with chlorinated water in a scrub process, ends removed, cut into sections, shredded (cross section $2.8 \times 2.8 \mathrm{~mm}$ ), and rinsed again with chlorinated water in an open flume. The chlorinated water, which was recirculated, was maintained at $\mathrm{pH} 6.8$ to 7.2 , with free chlorine 0.8 to $2.0 \mathrm{ppm}$. Chlorine was monitored with a diethyl-p-phenylenediamine test kit (Hach, Loveland, CO). The shredded carrots were vacuum packed but not flushed with gas. The area of the packaging film was $915 \mathrm{~cm}^{2} / \mathrm{bag}$; mean net weight was $440 \mathrm{~g}$, and mean volume of the filled bags was $700 \mathrm{~mL}$. Headspace was therefore $\sim 260 \mathrm{~mL}$. Filled bags were packed in cartons of $9 \mathrm{~kg}$ net weight. The packaging film was PD-961, a multilayer polyolefin $32 \mu \mathrm{m}$ thick, with specified $\mathrm{O}_{2}$ transmission rate of 60008000 and $\mathrm{CO}_{2}$ rate of $19000-22000 \mathrm{cc} \mathrm{m}^{2} \mathrm{day}^{-1} \mathrm{~atm}^{-1}$ at $23^{\circ} \mathrm{C}$ (Cryovac Div., Duncan, SC).

The shredded carrot was treated with ${ }^{60} \mathrm{Co}$ gamma irradiation at Food Technology Service, Inc. (Mulberry, FL) 1 to 2 days after packaging. Irradiation dosage was measured with 0.1 to $3.3 \mathrm{kGy}$ dosimeters (Harwell Laboratory, Oxfordshire, U.K.). Dosage was measured at the exterior of the package to determine the maximum and at the center to determine the minimum dosage for each treatment. Three separate irradiation treatments were conducted: for Trial 1 (March 6, 1996) there was control ( $0 \mathrm{kGy})$ and irradiated $(0.68-0.94 \mathrm{kGy})$; for Trial 2 (April 17) there was control, low dose $(0.15-0.20 \mathrm{kGy})$ and higher dose (0.42-0.48 kGy); and for Trial 3 (June 19) there was control, low dose $(0.16-0.22 \mathrm{kGy})$ and higher dose $(0.41-0.50$ $\mathrm{kGy}$ ). Storage times were measured from the time of irradiation. Storage temperature was $2^{\circ} \mathrm{C}$ except for the temperature-abuse samples, which were kept at $22^{\circ} \mathrm{C}, 65 \% \mathrm{RH}$. Samples for temperature abuse were either in original sealed bags or transferred from opened bags into sterile polyethylene bags of $65 \mathrm{~m}$ thickness, the open ends of which were folded and clamped to retard dehydration.

\section{Analytical techniques}

Headspace gas was taken from bags submerged in water. Samples were withdrawn by syringe through a septum that consisted of a 3 mm-thick layer of clear Permatex RTV silicone (Loctite Corp., Cleveland, $\mathrm{OH}$ ) on adhesive aluminum foil applied to plastic tape (Scotch Patch \& Repair tape, 3M), which was then applied to the bag. The syringe was flushed twice with headspace gas before collecting a sample. Within $10 \mathrm{~min}$ after withdrawal, the headspace gas was injected by means of a $50 \mu \mathrm{L}$ loop injector, to a gas chromatograph (Hewlett Packard 5890) fitted with a CTR-1 column (1.8 $\mathrm{m}$ long, $6 \mathrm{~mm}$ and 3 $\mathrm{mm}$ diameter outer and inner columns, respectively, Alltech, Deerfield, IL). Column flow rate was $70 \mathrm{~mL} / \mathrm{min}$ at $40^{\circ} \mathrm{C}$ column temperature. Headspace $\mathrm{O}_{2}$ and $\mathrm{CO}_{2}$ concentrations were calculated by comparison of peak areas (thermal conductivity detector at $120^{\circ} \mathrm{C}$ ) with standard gas mixtures.

Respiration rate at $3^{\circ} \mathrm{C}$ was determined in flow-through cells. The shredded carrot sample $(275 \mathrm{~g})$ was removed from the bags and placed in $1 \mathrm{~L}$ bottles ( 4 bottles/treatment), through which air was passed at 35 $\mathrm{mL} / \mathrm{min}$. The $\mathrm{CO}_{2}$ concentration of the outlet air after $24 \mathrm{hr}$ equilibri- 
um time was determined with a gas chromatograph (Hewlett Packard $3890)$ with GSQ column $(30 \mathrm{M} \times 0.53 \mathrm{~mm}$ i.d., J\&W Scientific). Samples were applied with a loop injector. Column flow rate was 10 $\mathrm{mL} / \mathrm{min}$, oven and thermal conductivity detector were at $40^{\circ} \mathrm{C}$ and $120^{\circ} \mathrm{C}$, respectively. In preliminary experiments in which the $\mathrm{CO}_{2}$ concentration was measured for up to 3 days we determined that equilibrium had been reached after $24 \mathrm{~h}$, which was sufficient time for $\mathrm{CO}_{2}$ absorbed in the carrots to have diffused out of the system.

Ethylene content of headspace gas was determined with the gas chromatograph using the GSQ column and flame ionization detector (at $250^{\circ} \mathrm{C}$ ). Injection was with split mode $\left(20: 1\right.$ split ratio), $250^{\circ} \mathrm{C}$ injector temperature. Two bags/treatment were analyzed in duplicate.

Ethanol content was determined with the gas chromatograph, using a FFAP column (Hewlett Packard) and flame ionization detector. Column flow was $4 \mathrm{~mL} / \mathrm{min}$. Column temperature was $55^{\circ} \mathrm{C}$ for injection, then increased to $70^{\circ} \mathrm{C}$ at $3^{\circ} \mathrm{C} / \mathrm{min}$. For sample preparation, 100 $\mathrm{mL}$ was blended with $100 \mathrm{~mL}$ water containing $1000 \mathrm{ppm}$ n-propanol as internal standard.

For determination of microbial populations a $100 \mathrm{~g}$ sample was mixed with an equal weight of buffered water and agitated $90 \mathrm{sec}$ in a paddle blender (the 'Masticator,' IUL, S.A., Barcelona, Spain). Three appropriate dilutions of the liquid were pipetted from the blended samples to determine the colony forming units per gram of carrot (CFU/g). Plate-count agar (Difco Laboratories, Detroit, MI), incubated at $35^{\circ} \mathrm{C}$ for 2 days, was used to determine total mesophilic microorganisms (Swan et al., 1992). Potato dextrose agar (Difco), incubated at $25^{\circ} \mathrm{C}$ for 3 days, was used to determine yeasts and molds (Mislivec et al., 1992). Each sample was from a separate $450 \mathrm{~g}$ bag. The colonies grown on five petri dishes of plate-count agar (average 500 colonies/treatment) were visually separated into morphological type, and five of each type were Gram-stained.

Oxygen permeability of packaging material was determined at $30^{\circ} \mathrm{C}$, $70 \%$ relative humidity with the Ox-Tran 100 (Modern Controls, Inc., Minneapolis, MN). This unit was calibrated with Polyester Film No. 1470 from National Bureau of Standards, and also an industry standard with permeance of $2300 \mathrm{~mL} / \mathrm{m}^{2}$ day.

Texture was determined with an Instron Model 1011 (Instron, Canton, MA), using a Kramer Shear Cell containing 35g sample. A $5000 \mathrm{~N}$ transducer was used, and the crosshead speed was $50 \mathrm{~mm} /$ min.

For headspace gases and microbial analyses, samples from five bags/treatment were analyzed separately. For ethanol, respiration rate and texture the contents of five bags were pooled and two replicates were analyzed for ethanol, four for respiration rate and 6 for texture. Statistical calculations were performed with Statistix software (Analytical Software, Tallahassee, FL). The error bars (Fig. 1) show standard error, except where this was smaller than the symbol.

\section{RESULTS \& DISCUSSION}

\section{Respiration rate and headspace gases}

The respiration rate was higher for irradiated than for control carrots after 2 days storage (Table 1 ). However, after 9 days storage the irradiated carrots had relatively lower respiration rate, possibly because the $\mathrm{CO}_{2}$ production was increased by microorganisms growing on the control carrots. Similar results were obtained in Trials 1 and 2 . For topped carrots respiration rates of $10-20 \mathrm{mg} \mathrm{CO}_{2} \mathrm{~kg}^{-1} \mathrm{hr}^{-1}$ at $\mathrm{O}^{\circ} \mathrm{C}$ and $13-26 \mathrm{mg} \mathrm{CO}_{2} \mathrm{~kg}^{-1} \mathrm{hr}^{-1}$ at $4-5^{\circ} \mathrm{C}$ have been reported (Hardenburg et al., 1990).

Headspace $\mathrm{O}_{2}$ was virtually the same for all levels of irradiation. One day after irradiation (two days after packing) the mean headspace $\mathrm{O}_{2}$ was 1.23 to $1.30 \%$ for all treatments $(0,0.19,0.45 \mathrm{kGy})$ for Trial 1. For samples stored at $2^{\circ} \mathrm{C}$ for 2,9 or 14 days after irradiation, the mean $\mathrm{O}_{2}$ was 1.16 to $1.22 \%$ (data not shown in tabular form). Similar levels of headspace $\mathrm{O}_{2}$ were observed in Trials 1 and 2. As indicated, each bag contained about $260 \mathrm{~mL}$ of headspace gases. At the measured respiration rates the carrots used $140-200 \mathrm{~mL} \mathrm{O}_{2} / \mathrm{bag} / \mathrm{d}$ (Table 1),
Table 1-Changes in respiration rate (RR), ethanol (EtOH) content and headspace $\mathrm{CO}_{2}$ of shredded carrots stored at $2^{\circ} \mathrm{C}$ in sealed bags after irradiation

\begin{tabular}{|c|c|c|c|c|c|c|c|c|c|}
\hline \multirow{2}{*}{$\begin{array}{l}\text { Irradiation } \\
\text { dose (kGy) }\end{array}$} & \multicolumn{3}{|c|}{2 days } & \multicolumn{3}{|c|}{9 days } & \multicolumn{3}{|c|}{14 days } \\
\hline & $\mathrm{RR}^{\mathrm{a}}$ & $\begin{array}{l}\text { EtOH } \\
\text { (ppm) }\end{array}$ & $\begin{array}{l}\mathrm{CO}_{2} \\
(\%)^{2}\end{array}$ & $\mathrm{RR}^{\mathrm{a}}$ & $\begin{array}{l}\text { EtOH } \\
\text { (ppm) }\end{array}$ & $\begin{array}{l}\mathrm{CO}_{2} \\
(\%)\end{array}$ & $\mathrm{RR}^{\mathrm{a}}$ & $\begin{array}{c}\mathrm{EtOH} \\
\text { (ppm) }\end{array}$ & $\begin{array}{c}\mathrm{CO}_{2} \\
(\%)\end{array}$ \\
\hline 0 & 26 & 440 & 14 & 31 & 3640 & 20 & 36 & 4910 & 17 \\
\hline $0.19^{b}$ & 29 & 770 & 16 & 25 & 3430 & 20 & 28 & 4560 & 17 \\
\hline $0.45^{c}$ & 30 & 690 & 18 & 26 & 3360 & 20 & 24 & 4490 & 19 \\
\hline SE & 0.7 & 42 & 0.8 & 0.7 & 230 & 0.8 & 0.7 & 300 & 0.8 \\
\hline
\end{tabular}

a $\mathrm{mg} \mathrm{CO} / \mathrm{kg} \mathrm{hr}$

b Minimum dose was $0.16 \mathrm{kGy}$; maximum dose was $0.22 \mathrm{kGy}$.

c For this treatment the minimum dose was $0.41 \mathrm{kGy}$, and the maximum was $0.54 \mathrm{kGy}$.

and therefore by the time the first headspace samples were analyzed 2 days after irradiation, the $30-40 \mathrm{~mL}$ of $\mathrm{O}_{2}$ trapped inside when the bags were sealed would have been consumed. Presumably the headspace $\mathrm{O}_{2}$ was low when the carrots were irradiated, which may be important, as Epp et al. (1968) reported that the effectiveness of irradiation in killing microorganisms was less at low oxygen levels.

Headspace $\mathrm{CO}_{2}$ was $17-20 \%$ after 9 or 14 days storage at $2^{\circ} \mathrm{C}$ for both control and irradiated (Table 1). After storage for 1 day headspace $\mathrm{CO}_{2}$ was $3-4 \%$ higher for irradiated than control (data not shown), indicating that irradiation at $0.5 \mathrm{kGy}$ caused roughly a $20 \%$ increase in $\mathrm{CO}_{2}$ output sometime during the first two days. Irradiation may sometimes cause an increase in respiration rate (Moy, 1983).

Headspace $\mathrm{CO}_{2}$ was also measured in samples stored at $22^{\circ} \mathrm{C}$ for 5 days to simulate temperature abuse. The headspace $\mathrm{CO}_{2}$ was $34 \%$ for samples with 0 or $0.19 \mathrm{kGy}$, and $30 \%$ for samples with $0.45 \mathrm{kGy}$, which indicated that headspace gas was affected much more by temperature than by irradiation (data not shown in tabular form).

The similarities in $\mathrm{O}_{2}$ and $\mathrm{CO}_{2}$ contents of headspace gases suggest that the packaging permeance need not be changed if carrots are irradiated. The measured permeance of the packaging film we used was $6400 \pm 190 \mathrm{~mL} / \mathrm{m}^{2}$ day at $30^{\circ} \mathrm{C}$. Carlin et al. (1989) reported that shredded carrots stored 14 days at $10^{\circ} \mathrm{C}$ in $25 \mathrm{~m}$ polyethylene had headspace $\mathrm{CO}_{2}$ of $16 \%$, about the same as we found at $2^{\circ} \mathrm{C}$ storage (Table 1).

\section{Ethanol}

The same conclusion, that temperature was more important than irradiation, applied to ethanol content of the carrots. The ethanol content was virtually the same whether or not carrots had been irradiated (Table 1). For samples stored in sealed bags the ethanol increased

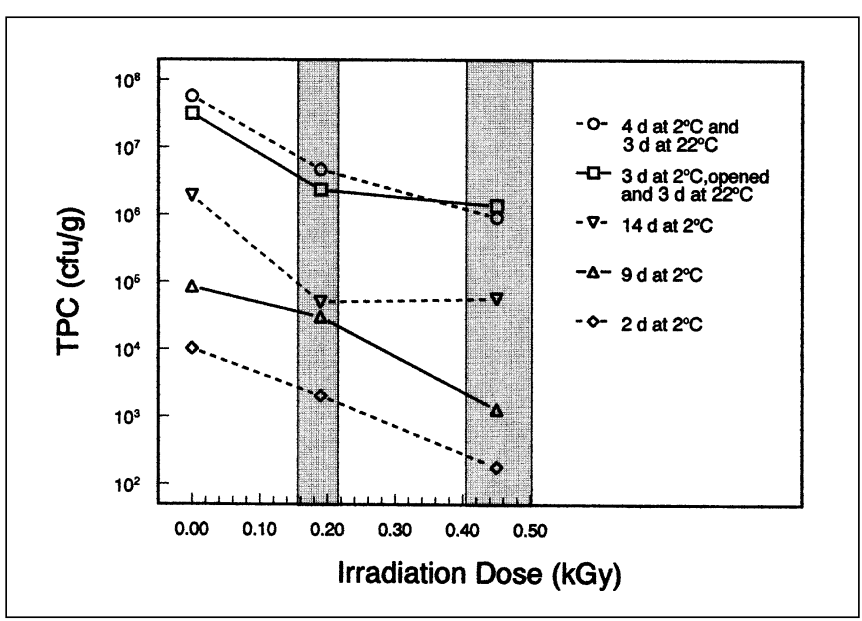

Fig. 1-Aerobic mesophiles in shredded carrots stored at $2^{\circ} \mathrm{C}$ in sealed bags (Trial 3 ). 
steadily with time, at a rate of $\sim 350 \mathrm{ppm} / \mathrm{d}$ when stored at $2^{\circ} \mathrm{C}$ (Table 1), $2000 \mathrm{ppm}$ if stored at $22^{\circ} \mathrm{C}$ (data not shown). However, ethanol was virtually unchanged over time for samples stored in opened bags. For example, carrots were removed from sealed bags after 14 days at $2^{\circ} \mathrm{C}$, when ethanol content was $4700 \pm 210 \mathrm{ppm}$ (Table 1). These samples were stored 2 more days at $22^{\circ} \mathrm{C}$, when the ethanol content was $4940 \pm 150 \mathrm{ppm}$ (data not shown). Probably ethanol was formed at a much slower rate in opened bags because of higher headspace oxygen, and possibly some ethanol evaporated from the carrots held in sealed bags. Similar results were obtained from other trials. Ethanol content of shredded carrots in sealed bags may be related to spoilage (Carlin et al., 1989). Marchetti et al. (1992) found only a weak relationship between microbial population and ethanol content for carrots stored in bags that were not sealed.

\section{Microbiology}

Shredded carrots irradiated at $0.45 \mathrm{kGy}$ had mean microbial populations, measured after two days at $2^{\circ} \mathrm{C}$, of $200 \mathrm{CFU} / \mathrm{g}$ compared to $12,000 \mathrm{CFU} / \mathrm{g}$ for nonirradiated control (Fig. 1). Large differences in microbial populations between irradiated and control persisted during different storage conditions (Fig. 1). Similar observations were found during Trials 1 and 2 .

Yeast populations were estimated from visual inspection of colonies on plate-count agar and also by growth on potato dextrose agar. Measured both ways, yeast populations were about $5 \%$ of microbial populations shown (Fig. 1) regardless of irradiation dosage, storage temperature or sampling time. Based on visual inspection of colonies sampled from incubated plate-count agar the microflora of irradiated samples were morphologically similar to those of nonirradiated carrots. Further, samples after 2,9 or 14 days at $2^{\circ} \mathrm{C}$ appeared morphologically similar. In all cases 94 to $97 \%$ of the bacteria were Gramnegative rod forms, with the remainder being cocci and Gram-positive rods, although this was not sufficient basis to conclude that the microbial population remained unchanged. Marchetti et al. (1992) found that lactic acid bacteria tended to outgrow competitors in grated carrots. Mossel et al. (1995) reported that Gram-negative rod forms tended to be more sensitive to irradiation than other types. In time some pathogens might outgrow their competitors when the microbial population is reduced by irradiation. However, the same could occur when microbial populations were decreased by pasteurization or chemical treatment.

For $2-14$ days after irradiation the microorganism mesophilic population of shredded carrots stored at $2^{\circ} \mathrm{C}$ doubled about every $1-$ 2 days for both control and irradiated samples (Fig 1). In contrast, Chervin and Boisseau (1994) reported virtually no increase in microbial populations for shredded carrots irradiated at $2 \mathrm{kGy}$ and stored at $10^{\circ} \mathrm{C}$ for 10 days. At the growth rate we observed it would take $1-2$ wk for the population to return to the same level it was before irradiation. This does not, however, imply that spoilage was delayed by that amount of time, as it has been shown that spoilage of grated carrot was not well correlated to the microbial population, and also not to ethanol, acidity or headspace $\mathrm{CO}_{2}$ values (Marchetti, et al., 1992, Carlin et al., 1989).

\section{Texture and acidity}

The texture as measured with the shear cell was virtually the same for irradiated and control. Mean stress was 3135, 3039 and 3082N for carrots with treatments of $0,0.17$ and $0.45 \mathrm{kGy}$, respectively (S.E. = $48 \mathrm{~N}$, Trial 3). Analysis of the data by multiple regression indicated a significant increase in shear force with time - but this amounted to only about $0.5 \% / \mathrm{d}$. That there was no important decrease in shear force suggests that $1 \%$ headspace $\mathrm{O}_{2}$ was not a problem at $2{ }^{\circ} \mathrm{C}$, although Carlin et al. (1989) had reported loss of firmness when the headspace contained $<1.5 \%$ and $>30 \% \mathrm{CO}_{2}$. For all 3 trials the head- space $\mathrm{CO}_{2}$ of refrigerated carrots was about $20 \%$, with all values well below $30 \%$.

Production of acetic and lactic acids in stored carrots has been reported (Carlin et al., 1989, Marchetti et al., 1992). In our work, the acidity was $0.10 \pm 0.01 \%$ (calculated as acetic) for all samples stored at $2^{\circ} \mathrm{C}$ for up to 14 days and also for 7 of 9 pooled samples stored at $22^{\circ} \mathrm{C}$ for up to 5 days. Significantly higher acidity $(0.14-0.18 \%)$ was found in two samples stored at $22^{\circ} \mathrm{C}$, although their ethanol content was not higher than samples that appeared edible (data not shown).

\section{Ethylene}

Mean ethylene content of the headspace inside the bags was $\sim 0.3$ ppm for carrots stored 2 to 19 days at $2^{\circ} \mathrm{C}$, whether nonirradiated or treated with $0.8 \mathrm{kGy}$ (Trial 1, results not shown). These low values suggest that increased ethylene production was not a problem for controls or for irradiated carrots.

\section{CONCLUSION}

USING A COMBINATION OF CHLORINE AND IRRADIATION AT 0.5 KGY, shredded carrots were produced with microbial population 2 days after irradiation of only $200 \mathrm{CFU} / \mathrm{g}$, compared to $13,000 \mathrm{CFU} / \mathrm{g}$ for nonirradiated control. Irradiation increased respiratory $\mathrm{CO}_{2}$ production during the first 2 days, but decreased it later, presumably as a result of lower bacteria load. Irradiation did not cause notable changes in acidity, ethanol or texture of shredded carrots. It is feasible to combine chlorination and low-dose irradiation to produce fresh-cut, shredded carrots with low levels of microorganisms.

\section{REFERENCES}

Baird-Parker, A.C. 1994. Foods and microbiological risks. Microbiology 140: 687695.

Bendig, J.W.A. and Strangeways, J.E.M. 1989. Listeria in hospital lettuce. Lancet, Mar. 18, 616-617.

Brackett, R.E. 1994. Microbiological spoilage and pathogens in minimally processed refrigerated fruits and vegetables. In Minimally Processed Refrigerated Fruits and Vegetables, R.C. Wiley (Ed.), p. 269-312. Chapman \& Hall, New York.

Vegetables, R.C. Wiley (Ed.), p. 269-312. Chapman \& Hall, New York.
Carlin, F., Nguyen-The, C., Cudennec, P., and Reich, M. 1989. Microbiological spoilage of fresh, ready-to-use grated carrots. Sci. Alim. 9: 371-386.

Chervin, C.L. and Boisseau, P. 1994. Quality maintenance of'ready-to-eat shredded carrots by gamma irradiation. J. Food Sci. 59: 359-361

Diehl, J.F. 1995. Safety of Irradiated Foods. Marcel Dekker, Inc., New York.

Epp, R.E., Weiss, H., and Santomasso, A. 1968. The oxygen effect in bacterial cells irradiated with high-intensity pulsed electrons. Radiation Research 34: 320-325. FDA. 1995. Section 179.26: Ionizing radiation for the treatment of food. In Code of Federal Regulations: Food and Drugs, Title 21, p. 389-390. U.S. Gov. Printing Office, Washington, DC

Hardenburg, R.E., Watada, A.E., and Wang, C.Y. 1990. The Commercial Storage of Fruits, Vegetables, and Florist and Nursery Stocks. Agr. Handbook 66. USDA/ARS. U.S. Government Printing Office, Washington, DC.

Marchetti, R., Casadei, M.A., and Guerzoni, M.E. 1992. Microbial population dynamics in ready-to-use vegetable salads. Ital. J. Food Sci. 2: 97-108.

Mislivec, P.B., Beuchat, L.R., and Cousin, M.A. 1992. Yeast and molds. In Compendium of Methods for the Microbiological Examination of Foods. p. 239-249. APHA, Washington, DC

Mossel, D.A.A., Corry, J.E.L., Struijk, C.B., and Baird. R.M. 1995. Essentials of the Mossel, D.A.A., Corry, J.E.L., Struijk, C.B., and Baird. R.M.
Microbiogy of Foods. John Wiley \& Sons, Chichester.

Moy, J.H. 1983. Radurization and radicidation: fruits and vegetables. Ch. 3 in Preservation of Food by Ionizing Radiation, Vol. III, E.S. Josephson and M.S. Peterson (Ed.), p. 83-108. CRC Press, Boca Raton, FL.

Nguyen-the, C. and Carlin, F. 1994. The microbiology of minimally processed fresh fruits and vegetables. Crit. Rev. Food Sci. Nutr. 34(4): 371-401.

Remington, J.S. and Schimpff, S.C. 1981. Please don't eat the salads. New England J. Med. 304(7): 433-435.

Scandella, D. and Foures, M. 1987. Effet de l'ionissation sur le maintien de la qualite des legumes de quatrieme gamme. Ind. Agric. Alim. 104: 911-916.

Swan, K.M.J., Busta, F.F., Peterson, E.H., and Johnson, M.G. 1992. Colony count methods. In Compendium of Methods for the Microbiological Examination of Foods. p. 75-95. APHA, Washington, DC.

U.S. Public Health Service and FDA. 1995. Section 3-502.12: Reduced oxygen packaging criteria. In Food Code, p. 62. U.S. Dept. Health Human Services, Washington, DC

Wiley, R.C. 1994. Preservation methods for minimally processed refrigerated fruits and vegetables. In Minimally Processed Refrigerated Fruits and Vegetables, R.C. Wiley (Ed.), p. 66-134. Chapman \& Hall, New York.

Ms received 12/12/97; revised 7/1/97; accepted 8/12/97.

We thank Charles R. Barmore for analytical methods for headspace $\mathrm{CO}_{2}$ and $\mathrm{O}_{2}$.

Mention of a trademark or proprietary product is for identification only and does not imply a guarantee or warranty of the product by the U.S. Department of Agriculture. All programs and services of the U.S. Department of Agriculture are offered on a nondiscriminatory basis without regard to race, color, national origin, religion, sex, age, marital status, or handicap. 